\title{
Avaliação do papel da calsarcina-1 no processo de diferenciação de mioblastos in vitro.
}

\section{Lizandra Maia de Sousa*, Ângela Julieth Buitrago Mejia, Renata Erbert Contriciani, Bianca Gazieri Castelucci, Sílvio Roberto Consonni}

\section{Resumo}

O disco Z, parte do sarcômero em células musculares estriadas, é constituído por proteínas envolvidas na mecanotransdução do meio extracelular ao intracelular e a distribuição de suas proteínas ao longo do desenvolvimento é necessária para a homeostase. Contudo, distúrbios na estrutura do sarcômero, seja por desarranjo das miofibrilas ou proteínas do disco Z, podem causar o desenvolvimento de cardiopatias ou distrofias musculares. Deste modo, o objetivo deste trabalho é elucidar alterações morfológicas e moleculares durante a diferenciação de mioblastos com formação de miotubos e sarcomerogênese para facilitar a compreensão das disfunções de proteínas associadas ao sarcômero.

Palavras-chave: Diferenciação celular, Mioblastos, Calsarcina-1.

\section{Introdução}

Distúrbios no sarcômero, particularmente no disco Z, podem resultar no desenvolvimento de cardiopatias ou distrofias musculares'. O disco Z limita os sarcômeros nas células musculares. Diversas proteínas participam da constituição do disco Z, como a a-actinina que promove a formação de um arcabouço para a inserção de proteínas estruturais que estão envolvidas na mecanotransdução entre o meio extracelular e intracelular. Além disso, moléculas sinalizadoras como Calcineurina, PKC e RhoA, caracterizam o disco Z como nicho de sinalização molecular para integração de múltiplas vias de transdução de sinais, como NFAT2,3,4. Destaca-se no disco Z, a via Calcineurina-NFAT, sensível à concentração de cálcio, por meio da sua atividade fosfatase medeia respostas de hipertrofia ${ }^{5}$. A calcineurina possui reguladores: as calsarcinas cujas três isoformas são específicas do músculo estriado e se localizam no disco Z. No músculo estriado esquelético, a ativação da calcineurina tem se mostrado necessária para o crescimento hipertrófico, levando a disfunções musculares associadas ao sarcômero ${ }^{6}$. Assim, o objetivo deste trabalho é elucidar as alterações morfológicas e moleculares durante a diferenciação de mioblastos com formação de miotubos e sarcomerogênese para facilitar a compreensão das disfunções de proteínas associadas ao sarcômero.

\section{Resultados e Discussão}

A partir da pergunta biológica e desenho experimental, foram utilizados mioblastos de músculo estriado esquelético, $\mathrm{C} 2 \mathrm{C} 12$ derivadas de camundongos $\mathrm{C} 3 \mathrm{H}$ para obtenção dos resultados. As células foram mantidas em meio de manutenção, DMEM FBS [10\% de soro fetal bovino $+1 \%$ penicilina-estreptomicina (PS)] e ao atingirem $70 \%$ de confluência, foram plaqueadas para indução a diferenciação. A indução foi realizada quando as células atingiram $100 \%$ de confluência em duas condições: 1) com o meio de manutenção DMEM FBS ou 2) com meio de diferenciação DMEM HS ( $2 \%$ soro de cavalo $+1 \%$ PS), trocados diariamente. Assim, foram estabelecidos os grupos: dia 0 (D0), dia 3 (D3) e dia 5 (D5) com FBS ou HS, para ensaios de microscopia de fluorescência com marcação de $\alpha$-actinina (proteína específica de disco Z), microscopia eletrônica de transmissão de células em monocamada (MET) para avaliação morfológica da sarcomerogênese e PCR em tempo real para investigação da expressão de genes envolvidos no processo de diferenciação e sarcomerogênese dos mioblastos em miotubos. Os resultados de imunofluorescência revelaram a expressão de $\alpha$-actinina nas células tratadas com DMEM HS D3 e D5, sugerindo que há o início da formação de sarcômeros e fusão células para formação de tubos alongados, morfologia inicial típica de uma fibra muscular estriada. Já as células tratadas com DMEM FBS não apresentam essas características. Os ensaios ultraestruturais confirmaram os resultados obtidos nos ensaios de imunofluorescência que as células D3 e D5 tratadas com DMEM HS apresentam estruturas elétrondensas dispostas perpendicularmente à organização das miofibrilas do citoesqueleto, semelhantes ao disco Z. E, em consonância aos resultados morfológicos, a análise por PCR em tempo real da expressão de genes envolvidos no processo de diferenciação de células musculares, tais como Troponina T, Troponina I, GATA 4, Nkx 2.5 e Calsarcina-1, mostrou que em células tratadas com HS houve uma maior expressão destes genes em relação às células tratadas com FBS. A próxima etapa do trabalho avaliará os efeitos do silenciamento da Calsarcina-1 no processo de diferenciação dos mioblastos in vitro.

\section{Conclusões}

Portanto, com este trabalho estabelecemos uma metodologia satisfatória para análise de formação miotubos e sarcomerogênese in vitro, a qual pode ser utilizada para compreensão de mecanismos que alteram a diferenciação de células musculares e resultam em cardiopatias ou distrofias musculares.

\section{Agradecimentos}

CNPq, PIBIC

\footnotetext{
${ }^{1}$ Frank, D., C. Kuhn, et al.. J Mol Med (Berl), v.84, n.6, Jun, p.446-68. 2006

${ }^{2}$ Frey,N.e E. N.Olson. J Biol Chem, v.277, n.16, Apr 19, p.13998-4004. 2002.

${ }^{3}$ Frank, D. e N. Frey. v.286, n.12, Mar 25, p.9897-904. 2011

${ }^{4}$ Frey, N., M. Luedde, et al. Nat Rev Cardiol, v.9, n.2, Feb, p.91-100. 2012

${ }^{5}$ Molkentin, J. D., J. R. Lu, et al.. Cell, v.93, n.2, Apr 17, p.215-28. 1998.

${ }^{6}$ Frey, N., J. A. Richardson, et al. Proc Natl Acad Sci U S A, v.97, n.26, Dec 19 p.14632-7. 2000.
} 